\title{
Analysis on Emotional Intelligence Levels of Physical Education and Sports Students in Sports
}

\author{
Ali Serdar Yücel ${ }^{1, *}$, Nahit Özdayi ${ }^{2}$ \\ ${ }^{1}$ Department of Sport Management, Faculty of Sports Sciences, Firat University, Turkey \\ ${ }^{2}$ School of Physical Education and Sports, Balıkesir University, Turkey
}

Copyright $\bigcirc 2019$ by authors, all rights reserved. Authors agree that this article remains permanently open access under the terms of the Creative Commons Attribution License 4.0 International License

\begin{abstract}
The purpose of this descriptive study is to compare the emotional intelligence levels and demographic attributes of students enrolled in different departments of Balıkesir University School of Physical Education and Sports during the 2018-2019 academic year. The research population was composed of 865 students receiving education in different departments of School of Physical Education and Sports, while the sample is composed of randomly selected 304 students among this population. The study utilized "Emotional Intelligence Inventory in Sports” developed by Schutte et al. (1998), revised and adapted by Lane et al. (2009) for use in sports with Turkish reliability and validity performed by Adiloğulları and Görgülü (2015). $\alpha=0.927$ was established as the reliability coefficient of the inventory. The Anova test, Kruskal Wallis test and Jonckheere-Terpstra test were used in data analysis. All analyses were performed with SPSS v17.0 (SPSS Science, Chicago, IL, USA). The study concluded emotional intelligence levels of the participants differ in the variable of age in the dimensions of using feelings, in the variable of department in the dimensions of evaluating one's own feelings and social skills, and finally a difference existed in the variable of age concerning life satisfaction. Moreover, no relation was ascertained between the emotional intelligence of the participants and their life satisfaction.
\end{abstract}

Keywords Emotional Intelligence, Sports, Student

\section{Introduction}

Emotional intelligence has increased in popularity within education and other fields in recent years [2]. Emotional intelligence plays a significant role in the communication among individuals. Individuals utilize emotional intelligence to process thoughts, feelings and reactions to circumstances encountered within their lives. From the conceptual perspective, emotional intelligence indicates the individual's ability to be aware of their own emotions as well as those of others and to manage their emotions accordingly [7]. Emotional intelligence brings together the fields of emotions and intelligence by viewing emotions as useful sources of information that help one to make sense of and navigate the social environment [24].The first branch of emotional intelligence, perceiving emotions, is the ability to detect and decipher emotions in faces, pictures, voices, and cultural artifacts. It also includes the ability to identify one's own emotions. Perceiving emotions may represent the most basic aspect of emotional intelligence, as it makes all other processing of emotional information possible [28].

Dulewicz and Higgs [11] define emotional intelligence as "awareness of emotions, control of relevant emotions, sustaining the power to resist these conditions under changing situations and state of consciousness directed to making sense of the feelings and thoughts of other individuals in more detail”.

Emotional intelligence is achieved by mental balance. Emotional intelligence is an important factor in establishing a balance within the individual's life, as well as assisting in the approaches of positive thinking, offering solutions and considering environmental factors. Thus, it has a significant effect in revealing the current skills of the individual concerning self-conscience, being focused on success, problem solving skills and establishing effective communication with other people [15]. Emotional intelligence also has a positive relationship with the concept of self-efficacy [4].

Emotional intelligence is a concept that can be developed over time. In this regard, emotional intelligence gains a place with experiences in time and it can be said to be nourished by the person's academic intelligence and reasoning skills [31].

\subsection{Emotional Intelligence and Athletic Skills}

In every sports activity, success depends on morphology, intellectual qualities and emotional characteristics of the athlete. Physiological and functional features, tactical knowledge and theoretical knowledge can be thought to form an equation with emotional intelligence [22]. 
Emotional intelligence and athletic skills affect each other. The levels of arousal and emotion control develop especially in sports fields that require fighting ambition [30].

\subsection{Factors That Create Emotional Intelligence}

Auto control, Motivation, Self-awareness, Empathy and Human Relations are five different concepts that have an effect on emergence of emotional intelligence. Among these, Empathy and self-awareness emerge as being the most important to determine the quality of the person's emotional intelligence, since these elements help the person to understand herself/himself and her/his environment [7].

Given that emotional intelligence begins with the individual and continues with the communication of the individual within the surrounding environment, the correct, positive and permanent steps taken by the individual to self-development will assist her/him to succeed in other aspects of their life [21].

\subsection{Factors Affecting the Development Process of Emotional Intelligence}

In the development of emotional intelligence, there are a number of factors that have an indirect impact that must be taken into consideration, investigated and tested. In general, the accepted factors which have an indirect effect on this development are follows [31]

Age: The development of emotional intelligence is indirectly related to the progress of the individual's age and her/his experience obtained in the aging process.

Sex: The emotional structures of women and men differ considerably.

Family and Environment: The family environment in which the individual has grown up in and the culture adopted over time contribute to the development of personality and habits.

These three main factors directly affect the individual's efforts to develop their identity. Additionally, individual experiences over time also contribute to personal development. The cumulative effect these factors determine individual feelings, whereas emotional intelligence allows one to regulate and manage those feelings and perspectives [31].

\section{Materials and Methods}

\subsection{Population and Sampling}

Data for this study were obtained from randomly selected 305 participants among 985 students studying in Balıkesir University School of Physical Education and Sports in the 2018-2019 academic year.

\subsection{Data Collection Techniques}

This is a descriptive study. In the study, "Emotional Intelligence Inventory in Sports" developed by Schutte et al. [29], revised and adapted by Lane et al. [20] for use in sports with Turkish reliability and validity performed by Adiloğulları and Görgülü [1] was used. Data forms were distributed to students by the researcher before or after the class within 2018-2019 academic year and they were requested to fill the form carefully after making the necessary explanations and providing the required environment, then the forms were collected for evaluation.

\subsection{Data Collection Tools}

The study relied heavily on "Emotional Intelligence Inventory in Sports" developed by Schutte et al. [29] and revised and adapted by Lane et al. [20] for use in sports. The reliability and validity of Turkish version was performed by Adiloğulları and Görgülü [1] and presented to Turkish researchers as available. The inventory is composed of five sub-dimensions namely evaluating others' feelings (5 items), evaluating one's own feelings (3 items), regulating feelings (2 items), social skills (3 items) and using feelings (6 items). The emotional intelligence inventory in sports, composed of 19 items and 5 sub-dimensions, was applied to a total of 404 (age $=20.80 \pm 2.17$ years) athletes. The sample was comprised of 157 women (age $=20.10 \pm 1.95$ years) and 247 men (age $=21.25 \pm 2.18$ years). The internal consistency coefficient of the scale by Adiloğulları and Görgülü was 0.91. A .05 level of significance was established when calculating statistical differences between groups in the study. Factor analysis was used to verify the emotional intelligence inventory.

Basic components and cyclic factor analysis method were used in the evaluation of emotional intelligence inventory. In this inventory, the distribution of 19 questions were evaluated by the sub-dimensions of "Evaluating others' feelings (5 items)", "Evaluating one's own feelings (3 items)", "Regulating feelings (2 items)", "Social skills (3 items)" and "Using feelings ( 6 items)". The suitability of the data for the factor analysis was assessed by the Bartlett test and the suitability of the size of the research group was evaluated by the Keizer-Meyer-Olkin coefficient. The internal consistency of the questionnaire was evaluated with Cronbach's Alpha coefficients obtained for each sub-dimension.

\subsection{Statistical Analysis}

About internal consistency we adopted the value $\alpha=0.927$ as the reliability coefficient of the inventory. Anova test, Independent Samples t-test, Kruskal Wallis test, Jonckheere-Terpstra test were also used in data analysis. All statistical operations were performed with SPSS 22.0. 


\section{Results}

Table 1. Descriptive Statistics of the Participants

\begin{tabular}{|c|c|c|c|}
\hline Variables & & Count & Column N \% \\
\hline \multirow{4}{*}{ Age } & $18-20$ & 131 & $43 \%$ \\
\hline & $21-23$ & 137 & $45 \%$ \\
\hline & $24-26$ & 31 & $10 \%$ \\
\hline & $27+$ & 5 & $2 \%$ \\
\hline \multirow{2}{*}{ Sex } & Male & 159 & $52 \%$ \\
\hline & Female & 145 & $48 \%$ \\
\hline \multirow{3}{*}{ Sports Branch } & Team Sports & 133 & $44 \%$ \\
\hline & Individual Sports & 115 & $38 \%$ \\
\hline & No & 56 & $18 \%$ \\
\hline \multirow{3}{*}{ Department } & Coaching Training & 130 & $43 \%$ \\
\hline & Physical Education and Sports Teaching & 74 & $24 \%$ \\
\hline & Sports Management & 100 & $33 \%$ \\
\hline \multirow{4}{*}{ Grade } & 1 & 83 & $27 \%$ \\
\hline & 2 & 91 & $30 \%$ \\
\hline & 3 & 67 & $22 \%$ \\
\hline & 4 & 63 & $21 \%$ \\
\hline \multirow{4}{*}{ How Many Years Have You Done Sports? } & 0 & 47 & $16 \%$ \\
\hline & $1-5$ & 73 & $24 \%$ \\
\hline & $6-10$ & 125 & $41 \%$ \\
\hline & $11+$ & 59 & $19 \%$ \\
\hline \multirow{4}{*}{ How Many Years Have You Been an Elite Athlete? } & 0 & 193 & $63 \%$ \\
\hline & $1-5$ & 87 & $29 \%$ \\
\hline & $6-10$ & 21 & $7 \%$ \\
\hline & $11+$ & 3 & $1 \%$ \\
\hline
\end{tabular}

Regarding Table 1, 43\% of the participants are aged between 18 and 20, $45 \%$ are at the age group of 21-23, the majority are male (52\%) and $44 \%$ are engaged in team sports. $43 \%$ of the participants receive coaching training, $25 \%$ receive_physical education and sports teaching and $33 \%$ receive sports management education while $27 \%$ is in the first grade, $30 \%$ is in the second grade, $22 \%$ is in the third grade and $21 \%$ is in the fourth grade. $24 \%$ of the participants do sports for $1-5$ years, $41 \%$ for $6-10$ years and
$19 \%$ for 11 years and more while $29 \%$ of them are elite for $1-5$ years, $7 \%$ for $6-10$ years and $1 \%$ for 11 years and more.

Concerning Table 2, the difference between the mean attitude scores of fans towards the club image by the variable of marital status was found to be significant $(p<0.05)$. It was ascertained that mean attitude scores of the single fans towards the club image $(X=29.73)$ were significantly higher than the mean attitude scores of the married fans towards the club image ( $X=27.93)$. 
Table 2. KMO and Bartlett's Test

\begin{tabular}{|c|c|c|}
\hline \multicolumn{2}{|c|}{ Kaiser-Meyer-Olkin Measure of Sampling Adequacy. } & .927 \\
\hline \multirow{3}{*}{ Bartlett's Test of Sphericity } & Approx. Chi-Square & 4296.229 \\
\hline & Df & 304 \\
\hline & Sig. & .000 \\
\hline
\end{tabular}

Factor load results obtained for each question are summarized in Table 3.

Table 3. Factor Loads Regarding Scale Items

\begin{tabular}{|c|c|c|c|c|c|}
\hline & $\begin{array}{l}\text { Evaluating Others' } \\
\text { Feelings }\end{array}$ & $\begin{array}{l}\text { Evaluating One's } \\
\text { Own feelings }\end{array}$ & Regulating feelings & Social Skills & $\begin{array}{l}\text { Using } \\
\text { Feelings }\end{array}$ \\
\hline $\begin{array}{l}\text { I can tell how people feel by looking at their } \\
\text { facial expressions. }\end{array}$ & 0.75 & & & & \\
\hline $\begin{array}{l}\text { When someone tells me an important event } \\
\text { about her/his life, I feel as if I experienced that } \\
\text { event myself. }\end{array}$ & 0.76 & & & & \\
\hline $\begin{array}{l}\text { I can tell what people feel only by looking at } \\
\text { their facial expressions. }\end{array}$ & 0.64 & & & & \\
\hline $\begin{array}{l}\text { It's hard for me to understand why people feel } \\
\text { that way. }\end{array}$ & 0.58 & & & & \\
\hline $\begin{array}{l}\text { I can tell how people feel themselves by } \\
\text { listening } \\
\text { to their voice. }\end{array}$ & 0.73 & & & & \\
\hline $\begin{array}{l}\text { I become aware of my feelings as I experience } \\
\text { them. }\end{array}$ & & 0.73 & & & \\
\hline I actually know why my feelings have changed. & & 0.75 & & & \\
\hline I easily recognize my feelings as I feel them. & & 0.53 & & & \\
\hline I have control over my feelings. & & & 0.66 & & \\
\hline $\begin{array}{l}\text { I seek and find the activities that make me } \\
\text { happy. }\end{array}$ & & & 0.43 & & \\
\hline I enjoy sharing my feelings with others. & & & & 0.49 & \\
\hline I organize activities that others will enjoy. & & & & 0.70 & \\
\hline $\begin{array}{l}\text { I help other people when they are sad to make } \\
\text { them feel better. }\end{array}$ & & & & 0.73 & \\
\hline $\begin{array}{l}\text { I see new possibilities when my mood is } \\
\text { positive. }\end{array}$ & & & & & 0.77 \\
\hline $\begin{array}{l}\text { I know how to sustain a positive feeling when I } \\
\text { live it. }\end{array}$ & & & & & 0.71 \\
\hline $\begin{array}{l}\text { Solving problems is easy for me when I am in a } \\
\text { good mood. }\end{array}$ & & & & & 0.76 \\
\hline I can find new ideas when my mood is positive. & & & & & 0.76 \\
\hline $\begin{array}{l}\text { I am inclined to find new ideas when I feel a } \\
\text { change in my feelings. }\end{array}$ & & & & & 0.73 \\
\hline $\begin{array}{l}\text { I use my good moods in order to sustain my } \\
\text { determination against obstacles. }\end{array}$ & & & & & 0.55 \\
\hline
\end{tabular}

The subtitles of the scale and mean, standard deviation and Cronbach's alpha values obtained for emotional intelligence inventory are summarized in Table 4.

Table 4. Reliability Statistics

\begin{tabular}{ccc}
\hline & Cronbach's Alpha & N of Items \\
\hline Evaluating Others' Feelings & .699 & 5 \\
\hline Evaluating One's Own Feelings & .849 & 3 \\
\hline Regulating feelings & .676 & 2 \\
\hline Social Skills & .706 & 3 \\
\hline Using Feelings & .898 & 6 \\
\hline
\end{tabular}

The inventory explains $68 \%$ of the total variance of emotional intelligence scale. The contribution of sub-dimensions of the scale to total variance was found to be $24 \%$ for evaluating others' feelings, $19 \%$ for evaluating one's own feelings, $10 \%$ for regulating feelings, $9 \%$ for social skills and $6 \%$ for using feelings. 
Table 5. Total Variance Analysis Results of the Scale

\begin{tabular}{lccccccccc}
\hline \multicolumn{1}{c}{ Component } & \multicolumn{3}{c}{ Initial Eigenvalues } & \multicolumn{2}{c}{ Extraction Sums of Squared Loadings } & \multicolumn{3}{c}{ Rotation Sums of Squared Loadings } \\
\hline & Total & $\begin{array}{c}\text { \% of } \\
\text { Variance }\end{array}$ & $\begin{array}{c}\text { Cumulative } \\
\%\end{array}$ & Total & $\begin{array}{c}\text { \% of } \\
\text { Variance }\end{array}$ & $\begin{array}{c}\text { Cumulative } \\
\%\end{array}$ & Total & $\begin{array}{c}\text { \% of } \\
\text { Variance }\end{array}$ & $\begin{array}{c}\text { Cumulative } \\
\%\end{array}$ \\
\hline $\begin{array}{l}\text { Evaluating Others' } \\
\text { Feelings }\end{array}$ & 8.46 & 44.55 & 44.55 & 8.46 & 44.55 & 44.55 & 4.56 & 24.04 & 24.04 \\
\hline $\begin{array}{l}\text { Evaluating One's } \\
\text { Own Feelings }\end{array}$ & 1.36 & 7.16 & 51.72 & 1.36 & 7.16 & 51.72 & 3.60 & 18.97 & 43.02 \\
\hline $\begin{array}{l}\text { Regulating feelings } \\
\text { Social Skills }\end{array}$ & 1.29 & 6.83 & 58.55 & 1.29 & 6.83 & 58.55 & 1.99 & 10.49 & 53.52 \\
\hline Using Feelings & .84 & 4.42 & 68.63 & .84 & 4.42 & 68.63 & 1.08 & 5.69 & 68.63 \\
\hline
\end{tabular}

Table 6. Anova Test Results Regarding the Variable of Age

\begin{tabular}{|c|c|c|c|c|c|c|}
\hline & & Sum of Squares & df & Mean Square & F & Sig. \\
\hline \multirow{3}{*}{ Evaluating Others' Feelings } & Between Groups & .966 & 3 & .322 & .674 & .003 \\
\hline & Within Groups & 143.76 & 301 & .478 & & \\
\hline & Total & 144.73 & 304 & & & \\
\hline \multirow{3}{*}{ Evaluating One’s Own Feelings } & Between Groups & 1.590 & 3 & .530 & .572 & .003 \\
\hline & Within Groups & 278.96 & 301 & .927 & & \\
\hline & Total & 280.55 & 304 & & & \\
\hline \multirow{3}{*}{ Regulating Feelings } & Between Groups & .347 & 3 & .116 & .133 & .037 \\
\hline & Within Groups & 261.79 & 301 & .870 & & \\
\hline & Total & 262.14 & 304 & & & \\
\hline \multirow{3}{*}{ Social Skills } & Between Groups & 1.814 & 3 & .605 & .764 & .001 \\
\hline & Within Groups & 238.15 & 301 & .791 & & \\
\hline & Total & 239.97 & 304 & & & \\
\hline \multirow{3}{*}{ Using Feelings } & Between Groups & .487 & 3 & .162 & .217 & .884 \\
\hline & Within Groups & 224.53 & 301 & .746 & & \\
\hline & Total & 225.02 & 304 & & & \\
\hline
\end{tabular}

$* \mathrm{p}<0.05$

Anova test was applied to understand whether emotional intelligence inventory differed by age. Anova test was also used to determine whether there was a difference in the responses given to the Emotional Intelligence Inventory between ages. The main hypothesis of the analysis expressed that there is no difference between ages. Following the test, the probability value calculated (Sig) was found to be lower than 0.05 value except for one factor. The main hypothesis of this factor was be rejected. Apart from the factor of using feelings, other factors significantly differ by age. According to the findings obtained, the factor of evaluating others' feelings differs by age. The mean values of $27+$ age group were the highest and 18-20 age group had the lowest values. The factor of evaluating one's own feelings differs by age. The 24-26 age group had the highest mean value while 18-20 age group had the lowest mean values. The factor of regulating feelings differs by age. $27+$ age group had the highest mean value while the lowest mean values belonged to the 18-20 age group. The factor of social skills differs by age. $27+$ age group had the highest mean value while the lowest mean values belonged to the 18-23 age group. The factor of using feelings did not differ by age.

Independent Samples t-test were applied to understand whether emotional intelligence inventory differed by sex. Test results were used to determine whether there was a difference in the responses given to the Emotional Intelligence Inventory between sexes. The main hypothesis of the analysis expressed that there is no difference between groups. Following the test, the probability value calculated (Sig) was found to be higher than 0.05 value except for two factors. The main hypothesis of this factor was be rejected. The factors of evaluating others' feelings and regulating feelings significantly differ by sex. According to the findings obtained, the factor of evaluating others' feelings differed by sex. The highest mean values belonged to females. The factor of evaluating one's own feelings did not by sex. The factor of regulating feelings differed by sex. The female group had the highest mean values. The factor of social skills did not differ by sex. The factor of using feelings did not differ by sex. 
Table 7. Descriptive Analyses Regarding the Variable of Age

\begin{tabular}{cccccc}
\hline & \multicolumn{3}{c}{ Mean } & & \\
\hline & $18-20$ & $21-23$ & $24-26$ & $27+$ \\
\hline Evaluating Others' Feelings & Mean & Mean & Mean & Mean \\
\hline Evaluating One's Own Feelings & 3.30 & 3.39 & 3.41 & 3.60 \\
\hline Regulating Feelings & 3.60 & 3.70 & 3.78 & 3.39 \\
\hline Social Skills & 3.57 & 3.62 & 3.65 & 3.75 \\
\hline Using Feelings & 3.51 & 3.51 & 3.26 & 3.56 \\
\hline
\end{tabular}

Table 8. Independent t-test Results by the Variable of Sex

\begin{tabular}{|c|c|c|c|c|c|c|c|c|c|c|}
\hline & & \multicolumn{4}{|c|}{ Levene's Test for Equality of Variances } & \multicolumn{3}{|c|}{ t-test for Equality of Means } & & \\
\hline & & \multirow[t]{2}{*}{$\mathrm{F}$} & \multirow[t]{2}{*}{ Sig. } & \multirow[t]{2}{*}{$\mathrm{T}$} & \multirow[t]{2}{*}{ df } & \multirow[t]{2}{*}{$\begin{array}{c}\text { Sig. } \\
\text { (2-tailed) }\end{array}$} & \multirow[t]{2}{*}{$\begin{array}{c}\text { Mean } \\
\text { Difference }\end{array}$} & \multirow[t]{2}{*}{$\begin{array}{l}\text { Std. Error } \\
\text { Difference }\end{array}$} & \multicolumn{2}{|c|}{$\begin{array}{c}\text { 95\% Confidence } \\
\text { Interval of the } \\
\text { Difference }\end{array}$} \\
\hline & & & & & & & & & Lower & Upper \\
\hline \multirow{2}{*}{$\begin{array}{l}\text { Evaluating } \\
\text { Others' Feelings }\end{array}$} & $\begin{array}{c}\text { Equal variances } \\
\text { assumed }\end{array}$ & 5.755 & .017 & -1.333 & 303 & .002 & -.10530 & .07899 & -.26073 & .05014 \\
\hline & $\begin{array}{c}\text { Equal variances not } \\
\text { assumed }\end{array}$ & & & -1.341 & 301.924 & .002 & -.10530 & .07850 & -.25978 & .04918 \\
\hline \multirow{2}{*}{$\begin{array}{l}\text { Evaluating } \\
\text { One’s Own } \\
\text { Feelings }\end{array}$} & $\begin{array}{c}\text { Equal variances } \\
\text { assumed }\end{array}$ & .000 & .989 & -.648 & 303 & .517 & -.07144 & .11022 & -.28834 & .14545 \\
\hline & $\begin{array}{c}\text { Equal variances not } \\
\text { assumed }\end{array}$ & & & -.646 & 296.623 & .518 & -.07144 & .11051 & -.28892 & .14604 \\
\hline \multirow{2}{*}{$\begin{array}{l}\text { Regulating } \\
\text { Feelings }\end{array}$} & $\begin{array}{c}\text { Equal variances } \\
\text { assumed }\end{array}$ & .604 & .438 & -1.382 & 303 & .002 & -.14692 & .10628 & -.35606 & .06223 \\
\hline & $\begin{array}{c}\text { Equal variances not } \\
\text { assumed }\end{array}$ & & & -1.385 & 302.378 & .002 & -.14692 & .10610 & -.35570 & .06187 \\
\hline \multirow{2}{*}{ Social Skills } & $\begin{array}{c}\text { Equal variances } \\
\text { assumed }\end{array}$ & 1.829 & .177 & -.730 & 303 & .466 & -.07439 & .10192 & -.27495 & .12616 \\
\hline & $\begin{array}{c}\text { Equal variances not } \\
\text { assumed }\end{array}$ & & & -.728 & 295.374 & .467 & -.07439 & .10225 & -.27562 & .12683 \\
\hline \multirow{2}{*}{ Using Feelings } & $\begin{array}{c}\text { Equal variances } \\
\text { assumed }\end{array}$ & 1.550 & .214 & -.568 & 303 & .571 & -.05606 & .09873 & -.25034 & .13822 \\
\hline & $\begin{array}{c}\text { Equal variances not } \\
\text { assumed }\end{array}$ & & & -.566 & 293.711 & .572 & -.05606 & .09912 & -.25113 & .13901 \\
\hline
\end{tabular}

Table 9. Descriptive Analyses for the Variable of Sex

\begin{tabular}{|c|c|c|}
\hline & \multicolumn{2}{|c|}{ Sex } \\
\hline & Male & Female \\
\hline & Mean & Mean \\
\hline Evaluating Others' eelings & 3.31 & 3.41 \\
\hline Evaluating One’s Own Feelings & 3.62 & 3.70 \\
\hline Regulating Feelings & 3.53 & 3.68 \\
\hline Social Skills & 3.45 & 3.53 \\
\hline Using Feelings & 3.55 & 3.61 \\
\hline
\end{tabular}

Table 10. Kruskal Wallis Test Results by the Sports Branch Results

\begin{tabular}{|c|c|c|c|}
\hline & Chi-square & df & Asymp. Sig. \\
\hline Evaluating Others' Feelings & .771 & 1 & .380 \\
\hline Evaluating One’s Own Feelings & .177 & 1 & .674 \\
\hline Regulating Feelings & .053 & 1 & .818 \\
\hline Social Skills & .167 & 1 & .003 \\
\hline Using Feelings & .276 & 1 & .000 \\
\hline
\end{tabular}


The Kruskal Wallis test was applied to understand whether emotional intelligence inventory differed by sports branches. Kruskal Wallis test results were used to determine whether there was a difference in the responses given to the Emotional Intelligence Inventory between sports branches. The main hypothesis of the analysis expressed that there was no difference between sports branches. Following the test, the probability value calculated (Sig) was found to be higher than 0.05 value except for two factors. The main hypotheses of two factors were rejected. The factors of social skills and using feelings significantly differ by the sports branch. According to the findings obtained, the factor of evaluating others' feelings did not differ by sports branch. The factor of evaluating one's own feelings did not differ by sports branch. The factor of regulating feelings did not differ by sports branch. The factor of social skills differs by sports branch. The mean value of social skills in the group of team sports was higher. The factor of using feelings did not differ by sports branch. The mean value of using feelings in the group of team sports as higher.
The Anova test was applied to understand whether emotional intelligence inventory differed by departments. Anova test was used to determine whether there was a difference in the responses given to the Emotional Intelligence Inventory between departments. The main hypothesis of the analysis expressed that there was no difference between departments. Following the test, the probability value calculated (Sig) was found to be higher than 0.05 value except for two factors. The main hypotheses of these two factors was rejected.

The factors of evaluating others' feelings and social skills significantly differ by department. According to the findings obtained, the factor of evaluating others' feelings differs by departments. The mean value of evaluating others' feelings was higher in the group studying sports management. The factor of evaluating one's own feelings did not differ by department. The factor of regulating feelings did not differ by department. The factor of social skills differs by department. The group studying coaching training had higher mean values of social skills. The factor of using feelings did not differ by department.

Table 11. Descriptive Analyses regarding the Variable of Sports Branch

\begin{tabular}{cccc}
\hline & \multicolumn{3}{c}{ Sports Branch } \\
\cline { 2 - 4 } & Team Sports & Individual Sports & Those not doing sports \\
\hline & Mean & Mean & Mean \\
\hline Evaluating Others' Feelings & 3.30 & 3.41 & 3.38 \\
\hline Evaluating One's Own Feelings & 3.60 & 3.61 & 3.89 \\
\hline Regulating Feelings & 3.59 & 3.62 & 3.61 \\
\hline Social Skills & 3.50 & 3.43 & 3.57 \\
\hline Using Feelings & 3.59 & 3.49 & 3.53 \\
\hline
\end{tabular}

Table 12. ANOVA Test Results regarding the Variable of Department

\begin{tabular}{|c|c|c|c|c|c|c|}
\hline & & Sum of Squares & $\mathrm{df}$ & $\begin{array}{c}\text { Mean } \\
\text { Square }\end{array}$ & $\mathrm{F}$ & Sig. \\
\hline \multirow{3}{*}{ Evaluating Others' Feelings } & Between Groups & .500 & 2 & .250 & .524 & .003 \\
\hline & Within Groups & 144.231 & 302 & .478 & & \\
\hline & Total & 144.731 & 304 & & & \\
\hline \multirow{3}{*}{ Evaluating One’s Own Feelings } & Between Groups & .305 & 2 & .153 & .164 & .848 \\
\hline & Within Groups & 280.253 & 302 & .928 & & \\
\hline & Total & 280.558 & 304 & & & \\
\hline \multirow{3}{*}{ Regulating Feelings } & Between Groups & .420 & 2 & .210 & .242 & .785 \\
\hline & Within Groups & 261.722 & 302 & .867 & & \\
\hline & Total & 262.143 & 304 & & & \\
\hline \multirow{3}{*}{ Social Skills } & Between Groups & 1.995 & 2 & .998 & 1.266 & .003 \\
\hline & Within Groups & 237.977 & 302 & .788 & & \\
\hline & Total & 239.972 & 304 & & & \\
\hline \multirow{3}{*}{ Using Feelings } & Between Groups & .317 & 2 & .159 & .213 & .808 \\
\hline & Within Groups & 224.705 & 302 & .744 & & \\
\hline & Total & 225.022 & 304 & & & \\
\hline
\end{tabular}


Table 13. Descriptive Analysis Results regarding the Variable of Department

\begin{tabular}{cccc}
\hline & \multicolumn{3}{c}{ Department } \\
\cline { 2 - 4 } & Coaching Training & Physical Education and Sports Teaching & Sports Management \\
\hline Evaluating Others' Feelings & Mean & Mean & Mean \\
\hline Evaluating One's Own Feelings & 3.31 & 3.37 & 3.40 \\
\hline Regulating Feelings & 3.69 & 3.64 & 3.62 \\
\hline Social Skills & 3.57 & 3.67 & 3.60 \\
\hline Using Feelings & 3.56 & 3.50 & 3.38 \\
\hline
\end{tabular}

Table 14. Jonckheere - Terpstra Test Results regarding the Variable of Grades

\begin{tabular}{cccccc}
\hline & $\begin{array}{c}\text { Evaluating Others' } \\
\text { Feelings }\end{array}$ & $\begin{array}{c}\text { Evaluating One’s Own } \\
\text { Feelings }\end{array}$ & $\begin{array}{c}\text { Regulating } \\
\text { Feelings }\end{array}$ & Social Skills & Using Feelings \\
\hline Number of Levels in Grade & 4 & 4 & 4 & 4 & 4 \\
\hline $\mathrm{N}$ & 305 & 305 & 305 & 305 & 305 \\
\hline Observed J-T Statistic & 19482.000 & 18172.000 & 18754.500 & 17554.500 & 18860.500 \\
\hline Mean J-T Statistic & 17315.500 & 17315.500 & 17315.500 & 17315.500 & 17315.500 \\
\hline Std. Deviation of J-T Statistic & 854.505 & 848.654 & 845.559 & 851.863 & 855.921 \\
\hline Std. J-T Statistic & 2.535 & 1.009 & 1.702 & .281 & 1.805 \\
\hline Asymp. Sig. (2-tailed) & .011 & .313 & .089 & .779 & .071 \\
\hline
\end{tabular}

Table 15. Descriptive Analyses regarding the Variable of Grade

\begin{tabular}{ccccc}
\hline & \multicolumn{2}{c}{ GRADE } \\
\cline { 2 - 5 } & 1 & 2 & 3 & Mean \\
\hline Evaluating Others' Feelings & Mean & Mean & 3.40 & 3.40 \\
\hline Evaluating One's Own Feelings & 3.18 & 3.45 & 3.40 & 3.68 \\
\hline Regulating Feelings & 3.49 & 3.73 & 3.74 & 3.69 \\
\hline Social Skills & 3.36 & 3.68 & 3.51 & 3.45 \\
\hline Using Feelings & 3.47 & 3.51 & 3.61 & 3.67 \\
\hline
\end{tabular}

The Jonckheere-Terpstra test was applied to understand whether emotional intelligence inventory differed by grades. Jonckheere-Terpstra test results were used to determine whether there was a difference in the responses given to the Emotional Intelligence Inventory between grades. The main hypothesis of the analysis expressed that there was no difference between grades. Following the test, the probability value calculated (Sig) was found to be higher than 0.05 value except for one factor. The main hypothesis of this one factor was rejected. The factor of evaluating others' feelings significantly differs by grade. According to the findings obtained, the factor of evaluating others' feelings differs by grades. The mean value of evaluating others' feelings was higher in the $2^{\text {nd }}$ grades. The factor of evaluating one's own feelings did not differ by grades. The factor of regulating feelings did not differ by grades. The factor of social skills did not differ by grades. The factor of using feelings differs by grades.

\section{Discussion}

The purpose of this study was to compare the demographic attributes and emotional intelligence levels of students studying in different departments of Balıkesir University School of Physical Education and Sports in the 2018-2019 academic year.

Analyzing the emotional intelligence levels by the variable of age, it was observed that the factor values of using feelings and regulating feelings were the highest in $27+$ age group. This result indicated that the individuals newly entering into adulthood use and regulate their feelings better. The factor of evaluating one's own feelings was the highest in 24-26 age group. In the study of Adiloğulları [3] and Adiloğulları et al. [2] performed on teachers, it was stated that as age increases, the higher emotional intelligence levels become. In the literature, this shows parallelism with the thesis of Roitman [26], Dal [9] 
and Goleman [14] "emotional intelligence presents a lifelong development". As a person matures and self-awareness increases, emotional intelligence also develops. This circumstance is best explained by the fact that as a person progresses through life experiences one is better able to adapt and respond more realistically in the face of the events [16]. In the previous studies, significant differences were also found between age and emotional intelligence levels and emotional intelligence was stated to increase together with age $[8,13,10,17]$.

Analyzing the emotional intelligence skills by the variable of sex, it was observed that the factors of evaluating others' feelings and regulating feelings are higher in women. The fact that female participants have higher emotional intelligence averages than male participants has been explained with the notion that women have different genetic characteristics and therefore attach more importance and significance to emotions [23]. Similar results have been obtained in the relevant literature [16]. Emotional intelligence scores of women have been found to be higher than men [12, 5, 13, 17].

Analyzing the emotional intelligence levels by the variable of sports branch, the factors of social skills and using feelings were observed to be higher in athletes doing team sports. Team sports help individuals be more socialized, communicate with people better, stand firmly while losing, create a team spirit and cooperate [27]. Thus, the athletes doing team sports are better at the dimensions of social skills and using feelings. The findings obtained are supported with relevant literature [25].

Analyzing the factor of evaluating others' feelings by the variable of department studied, the averages were observed to be higher in those studying sports management compared to other departments. Analyzing the factor of social skills by the department studied, the averages were observed to be higher in those studying coaching training compared to other departments. High averages of social skills belonging to the students studying coaching training indicate that students studying in this department are self-confident, friendly and social individuals who act in accordance with the environment in social situations, can interpret the feelings of others accurately and fully, are able to empathize, have the skills of initiating and directing conversations in any matter. This result complies with the study conducted by Avşar [6].

Analyzing the emotional intelligence skills by the variable of grade, the factor of evaluating others' feelings was observed to be higher in the $2^{\text {nd }}$ grade students compared to other grades. Emotional intelligence was expected to improve together with age and education received in higher grades. Our findings were not by other studies identified in the literature $[18,19]$.

\section{Conclusions}

In conclusion, significant differences among participants were identified when comparing emotional intelligence levels and the dimensions of age, sex, sports branch, grade and department. Emotional intelligence levels differed in favor of the 27+ age group, the 24-26 age group and the $2^{\text {nd }}$ grade students engaged in team sports and studying sports management and coaching.

\section{Acknowledgements}

The authors wish to thank the participants for the cooperation with the study,

\section{Conflicts of Interest}

The authors declare no conflict of interest.

\section{Funding}

This research received no external funding.

\section{REFERENCES}

[1] Adiloğulları, İ., Görgülü, R. (2015). Sporda Duygusal Zekâ Envanteri'nin Uyarlama Calışması, Spor, Egzersiz ve Antrenman Bilimleri Dergisi, Volume 1, No 2, 83-94.

[2] Adiloğulları, İ., Ulucan, H., Senel, E. (2014). Analysis of the relationship between the emotional intelligence and professional burnout levels of teachers. Educational Research and Reviews, 9(1), p.1-8.DOI: 10.5897/ERR2013.1670

[3] Adilogullari, İ. (2011). The teachers level of emotional intelligence some of the demographic variables for investigation. Educational Research and Reviews, 6(13), 786-792.

[4] Adiloğulları, I., Senel, E. (2014). Examination of the Relationship between General Self-efficacy Beliefs, Emotional Intelligence Levels and Emotional Self-efficacy Levels of Students in School of Physical Education and Sport, The Anthropologist, 18:3, 893-902, DOI: 10.1080/09720073.2014.11891621

[5] Austin, E.J., Evans, P., Magnus, B., O’Hanlon, K.A. (2007). Preliminary Study of Empathy Emotional Intelligence and Examination Performance in MBChB Student. Medical Education; 41(7), 684-689.

[6] Avşar, Z. (2004). Beden Eğitimi ve Spor Öğretmenlerinin Sosyal Beceri Düzeylerinin Belirlenmesi, Eğitim Fakültesi Dergisi XVII (2), 111-130.

[7] Çetinkaya, Ö., Alparslan, A. M. (2011). Duygusal Zekânın İletişim Becerileri Üzerine Etkisi: Üniversite Öğrencileri Üzerinde Bir Araştırma. Süleyman Demirel University, İktisadi ve İdari Bilimler Fakültesi Dergisi, 16(1), 363-377.

[8] Çoban, B., Karademir, T., Açak, M., Devecioğlu, S. (2010). 
The Emotional Intelligence of Students Who Are Sitting A Special-Ability Examination Social Behavior and Personality, 38 (8), 1123- $1134 \quad$ DOI 10.2224/sbp.2010.38.8.1123

[9] Dal, E. (2015). Kadınlardaki Duygusal Zeka Düzeyi İle Yaşam Doyumu Arasındaki İlişkinin İncelenmesi. Üsküdar University Department of Clinical Pscyhology, Master's Thesis.

[10] Dicle, A.N. (2006). Üniversite Öğrencilerinin Sosyal Beceri Düzeylerinin Duygusal Zeka ve Bazı Kişisel Özelliklerine Göre İncelenmesi. Master's Thesis. Samsun: Ondokuz Mayıs University Institute of Social Sciences

[11] Dulewicz, V., Higgs, M. (1999). Can Emotional Intelligence Be Measured And Developed? Leadership\& Organizational Development Journal, 20 (5), 242-253.

[12] Erdoğdu, Y.M. (2008). Duygusal Zekanın Bazı Değişkenler Açısından İncelenmesi. Elektronik Sosyal Bilimler Dergisi; 7(23), 62-76.

[13] Göçet, E. (2006). Üniversite Öğrencilerinin Duygusal Zeka Düzeyleri İle Stresle Başa Çıkma Tutumları Arasındaki İlişki. Master’s Thesis. Sakarya: Sakarya University Institute of Social Sciences.

[14] Goleman, D.P. (2014), Duygusal Zekâ Neden IQ’ dan Daha Önemlidir?, B. Seçkin Yüksel (Translator), İstanbul: Varlık Yayınları.

[15] Harrod, N.R., Scheer, S.D. (2005). An Explanation of Adolescent Emotional Intelligence in Relation to Demographic Characteristics. Adolescence, Vol: 40, No: 159, pp. 503-512.

[16] Karademir, T., Döşyılmaz, E., Coban, B., Kafkas, M.E. (2010). Beden Eğitimi ve spor bölümü özel yetenek sınavına katılan öğrencilerde benlik saygısı ve duygusal zekâ. Kastamonu Eğitim Dergisi, 18 (2), 653-674.

[17] Karakaş, A.S., Küçükoğlu, S. (2011). Bir Eğitim Hastanesinde Çalışan Hemşirelerin Duygusal Zeka Düzeyleri, Anadolu Hemşirelik Ve Sağlık Bilimleri Dergisi, 14: 3.

[18] Kızıl, Z. (2012). Eğitim Bilimleri Fakültesi Öğrencilerinin Duygusal Zekalarının Çeşitli Değişkenler Açısından İncelenmesi, Master's Thesis, Ankara University, Institute of Educational Sciences, Ankara.

[19] Köksal, A. (2003). Ergenlerde Duygusal Zeka ile Karar Verme Stratejileri Arasındaki İlișki, Master's Thesis, İstanbul University Institute of Social Sciences, İstanbul.

[20] Lane, A.M., Meyer, B.B., Devonport, T.J., Kevin, A.D., Thelwell, R., Gill, G.S., Diehl, C.D.P., Wilson, M., Weston, $\mathrm{N}$ (2009). Validation of the emotional intelligence scale for use in sport. Journal of Sport Science and Medicine, 8, 289-295.

[21] Lopes, P.N. (2004). Emotional Intelligence and Social Interaction. Personality and Social Psychology Bulletin, No: 30, 1018-1034.

[22] Lozovina, M., Bonacin, D., Lozovina, V. (2012). Emotional Intelligence and Determination of Sociometric Status in Sport, Sport Science 5, 2, 66- 74.

[23] Mayer, J.D., Salovey, P., Caruso, D. (2000). “Emotional
Intelligence as Zeitgeist as Personality, and as Mental Ability” in Reuven Bar-On; James D. A. Parker (Eds.). The Handbook of Emotional Intelligence (pp. 92-117). USA: Jossey- Bass

[24] Mayer, J.D., \& Salovey, P. (1997). What is emotional intelligence? In P. Salovey \& D. Sluyter (Eds.), Emotional development and emotional intelligence: Educational implications (pp. 3-31). New York: Basic Books

[25] Özdenk, S. (2018). Sporda duygusal zeka ve liderlik, Gazi kitabevi, May.

[26] Roitman, J.D. (1999). Emotional Intelligence: The Heart is Smarter than the Brain, Boulder: University of Colorado.

[27] Salar, B., Hekim, M., Tokgöz, M. (2012). 15-18 yaş grubu takım ve ferdi spor yapan bireylerin duygusal durumlarının karşılaştırılması. Mehmet Akif Ersoy University Sosyal Bilimler Enstitüsü Dergisi Year: 4 No: 6.

[28] Salovey, P., \& Grewal, D. (2005). The Science of Emotional Intelligence. Current Directions in Psychological Science, $14,281-285$

[29] Schutte, N.S., Malouff, J.M., Hall, L.E., Haggerty, D.J., Cooper, J.T., Golden, C.J., Dornheim, L. (1998). Development andvalidation of a measure of emotional intelligence. Personality and Individual Differences, Vol. 25, 167-177.

[30] Szabo, A., Urbán, F. (2014). Do Combat Sports Develop Emotional Intelligence, Kinesiology 46, 1, 53-60.

[31] Tuğrul, C. (1999). Duygusal Zekâ, Klinik Psikiyatri, No: 1, 12-20. 